\title{
NSF celebrates half a century with big plans
}

\section{Washington}

As the National Science Foundation (NSF) approaches its fiftieth birthday next week, its prospects have seldom looked brighter.

The Clinton administration has proposed a $\$ 675$ million budget increase next year for the agency, which funds most nonbiomedical research at US universities. This is by far the largest increase in its history, and there are frequent statements of support for it in the US Congress.

The NSF has been asked to lead most of the government's recent science initiatives, such as those in computing and in nanotechnology. Rita Colwell, the marine biologist who became NSF director in 1998, talks publicly of raising its existing budget of $\$ 4$ billion to $\$ 8$ billion, or more. These are large numbers for an agency which, although highly respected around the world for the quality of its work, has served for most of its history as a relatively small component of the US government's $\$ 80$ billion annual research and development effort.

The National Science Foundation Act was passed in 1950, after five years of wrangling about how the US government should continue the large-scale support for research begun during the Second World War. The delay meant that the NSF started small, supporting academic research in those disciplines that other areas of government - such as the National Institutes of Health, the Naval Research Laboratory and the Atomic Energy Commission - had not grabbed for themselves in the immediate post-war period.

The Soviet Union's launch of Sputnik in 1957 inspired an upsurge in the agency's fortunes (see graph). But its budget then remained essentially flat until the early 1980 s, when economists and politicians began to associate basic research with economic growth. This association has gained acceptance during the recent economic boom.

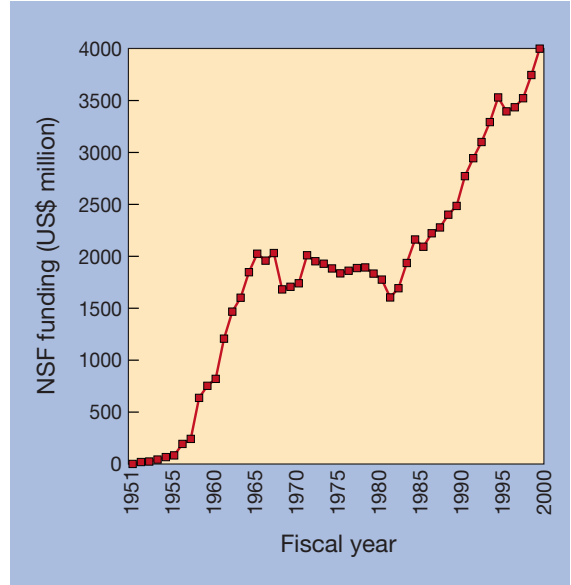

On the up: recent political enthusiasm for basic research has been good for the NSF's budget.

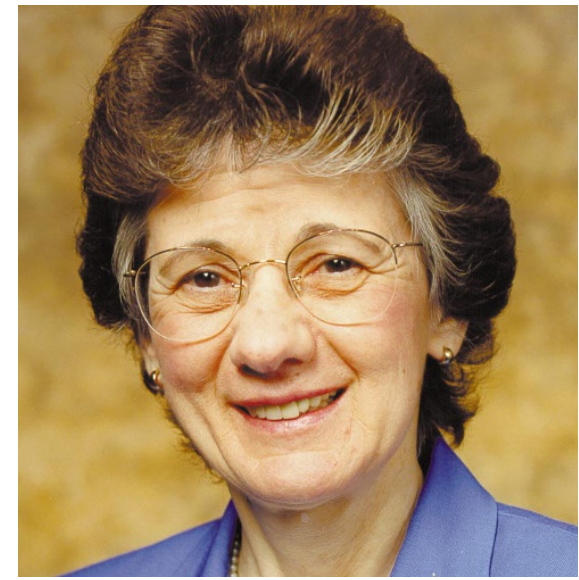

Colwell: NSF director is "guardedly optimistic" that Congress will grant a record budget request.

"For the first time, there's a growing recognition of the impact of basic research on the quality of life, and the impact of the NSF on basic research," says Eamon Kelly, an economist at Tulane University in Louisiana and chairman of the National Science Board, the presidentially appointed committee which supervises the NSF.

"Basic research wasn't so valued during the Cold War years," agrees Howard Silver, chairman of the Coalition for National Science Funding, which lobbies for the NSF in Washington. "People are now making connections between basic research and prosperity, better medicine and good times."

The NSF is seen by the administration, and by members of Congress who are interested in science and technology, as an efficient funding source of such basic research. It has no laboratories of its own, but, despite the bureaucracy of its headquarters in an office building in northern Virginia, it maintains close ties with the academic community.

About one third of its programme managers, who vet grant applications and arrange for their review, are academics temporarily seconded to the agency. "It's the closest thing you get to a university environment inside the government," says George Mazuzan, who recently retired as the NSF's historian. "There's a profusion of outside influence that other agency's don't get."

The agency has always been characterized by a competent, low-key management style. "By and large it has had good managers there have been no real losers," says Frank Press, former president of the US National Academy of Sciences and science adviser to President Jimmy Carter. "And the politicians have more or less stayed away from it."

But this mild-mannered approach has its limitations, observers point out. The academics who have led the agency "are not very politically acute people," says Dan Greenberg, a columnist for The Washington Post and visiting scholar at Johns Hopkins University in Baltimore.

Since her appointment, Colwell has been trying to change that. From the outset, she told sometimes disbelieving audiences that the National Science Foundation could become an $\$ 8$ billion agency. Her tone contrasted sharply with the always-cautious public statements of her predecessor, Neal Lane (who left to become Clinton's science adviser), and surprised some long-time observers. Now, however, "the community has grown to see that her style might have some benefits," according to Sam Rankin, associate executive director of the American Mathematical Society.

The main such benefit has been the administration's unprecedented request for a $\$ 675$ million budget hike, which, as Colwell pointed out at an NSF birthday event last week, is twice as large in dollar terms as any previous budget request in the agency's history. Congress appropriations committees will now decide how much of this should be granted.

"Very strong support has been expressed for us because of the work we do for the country," says Colwell. "We are guardedly optimistic."

But as Colwell works the marble halls of Capitol Hill this spring to secure backing for the increase, she faces the same problem as her predecessors. The agency is widely liked, but it lacks any individual champion who will defend it to the death. Senator Barbara Mikulski (Democrat, Maryland), for example, will protect the NASA budget, which secures thousands of jobs at the Goddard Space Center, to her last breath - and most of the programmes that compete with NSF for funds have similar protection. As Rankin puts it: "No-one will go to the wall for NSF."

The NSF is working to broaden its appeal. Its anniversary celebrations, starting with last week's event at which Colwell and Nobel laureate Leon Lederman taught Washington schoolchildren how to do science, will emphasize the foundation's school education programmes. "Science education is a serious business, but it's also great fun," Lederman told the children.

Colwell invited accomplished scientists to join the 240 already taking part in an anniversary programme introducing children aged between 12 and 14 to science. In addition, a competition held in the Sunday newspaper magazine Parade asks children to submit their ideas for applying science to "national and global problems".

Kelly says that the NSF made a "conscious decision" to focus the anniversary celebrations on the public. "We've not done a good job of communicating what the agency does to the general public," he says. Colin Macilwain 